\title{
“Accidental” Diagnosis of a Silent Giant Hydronephrosis
}

\author{
Sessiz Bir Dev Hidronefrozun "Rastlantısal” Tanısı
}

\author{
(1) Mohamad Syafeeq Faeez Md Noh', (1) Anna Misyail Abdul Rashid ${ }^{2}$ \\ 'University Putra Malaysia Faculty of Medicine and Health Sciences, Department of Imaging, Serdang, Malaysia \\ ${ }^{2}$ University Putra Malaysia Faculty of Medicine and Health Sciences, Department of Medicine, Serdang, Malaysia
}

\begin{abstract}
Giant hydronephrosis is defined as the presence of more than $1000 \mathrm{~mL}$ of fluid in the collecting system. While usually affecting children, uncommonly, adults may be affected, and it can be mistakenly diagnosed as a tumor. We present a case of silent giant hydronephrosis in an adult, misdiagnosed initially as a tumor, and subsequently confirmed as giant hydronephrosis postoperatively.
\end{abstract}

Keywords: Giant hydronephrosis, Computed tomography, Calculus, Renal tumor

\section{Öz}

Dev hidronefroz, toplayıcı sistemde 1000 mL'den daha fazla sıvının varlığı olarak tanımlanmaktadır. Genellikle çocukları etkilerken, nadiren yetişkinler de etkilenebilir ve yanlışıkla bir tümör olarak teşhis edilebilir. Başlangıçta tümör olarak yanlış tanı konulan ve akabinde ameliyat sonrası sessiz dev hidronefroz olarak onaylanan bir yetişkinde, sessiz dev hidronefroz olgusunu sunuyoruz.

Anahtar Kelimeler: Dev hidronefroz, Bilgisayarlı tomografi, Taş, Renal tümör

\section{Introduction}

Giant hydronephrosis in the paediatric population is most commonly due to ureteropelvic junction obstruction; in more than half of these cases, this obstruction is functional rather than anatomical. When occurring in adults, this clinical entity presents a diagnostic challenge, as more often than not, a diagnosis of a tumor will be made. Cross sectional imaging via computed tomography (CT) or magnetic resonance imaging allows a detailed assessment to be made prior to surgical planning. We describe, in our experience, a patient with silent giant hydronephrosis due to a ureteric calculus, who was eventually diagnosed with silent giant hydronephrosis post trauma. The preoperative CT findings in our case are described.

\section{Case Presentation}

A previously well 54-year-old man presented with acute onset hematuria and lower abdominal pain, after falling down while riding his bicycle. This was the first episode. He had no other complaints.
On physical examination, the abdomen appeared mildly distended. Minimal tenderness was noted on palpation of the lower abdomen, with no obvious bruising. Laboratory test results were all normal, except for red blood cells present in urinalysis.

A suspicion of injury to the urogenital organs prompted an urgent contrast enhanced CT of the abdomen which showed a huge mass, mainly located on the right side of the abdomen, occupying almost the entirety of the abdomen, measuring approximately $15 \mathrm{~cm} \times 25 \mathrm{~cm} \times 35 \mathrm{~cm}$ (antero-posterior $x$ width $x$ cranio-caudal). It was seen that the mass was displacing the liver superiorly, the bowels and most of the abdominal organs confined to the left side, and the pelvic organs inferiorly. Minimal enhancement with septation was noted; with an area of avid enhancement posteriorly, and heterogenous enhancement centrally (Figures 1a, b). An $8 \mathrm{~mm}$ calculus was seen in the proximal right ureter, which was displaced from its normal anatomical position (Figure 2). No invasion of the surrounding structures was seen. A renal tumor with incidental finding of calculus was initially suspected.

Correspondence: Mohamad Syafeeq Faeez Md Noh MD, University Putra Malaysia Faculty of Medicine and Health Sciences, Department of Imaging,

Serdang, Malaysia

Phone: +60123975025 E-mail: msf.mdnoh@gmail.com ORCID-ID: orcid.org/0000-0001-9386-8914

Received: 25.07.2017 Accepted: 19.09.2017

Cite this article as: Md Noh MSF, Abdul Rashid AM. "Accidental" Diagnosis of a Silent Giant Hydronephrosis. J Urol Surg 2018;5(3):206-208.

๑Copyright 2018 by the Association of Urological Surgery / Journal of Urological Surgery published by Galenos Publishing House. 

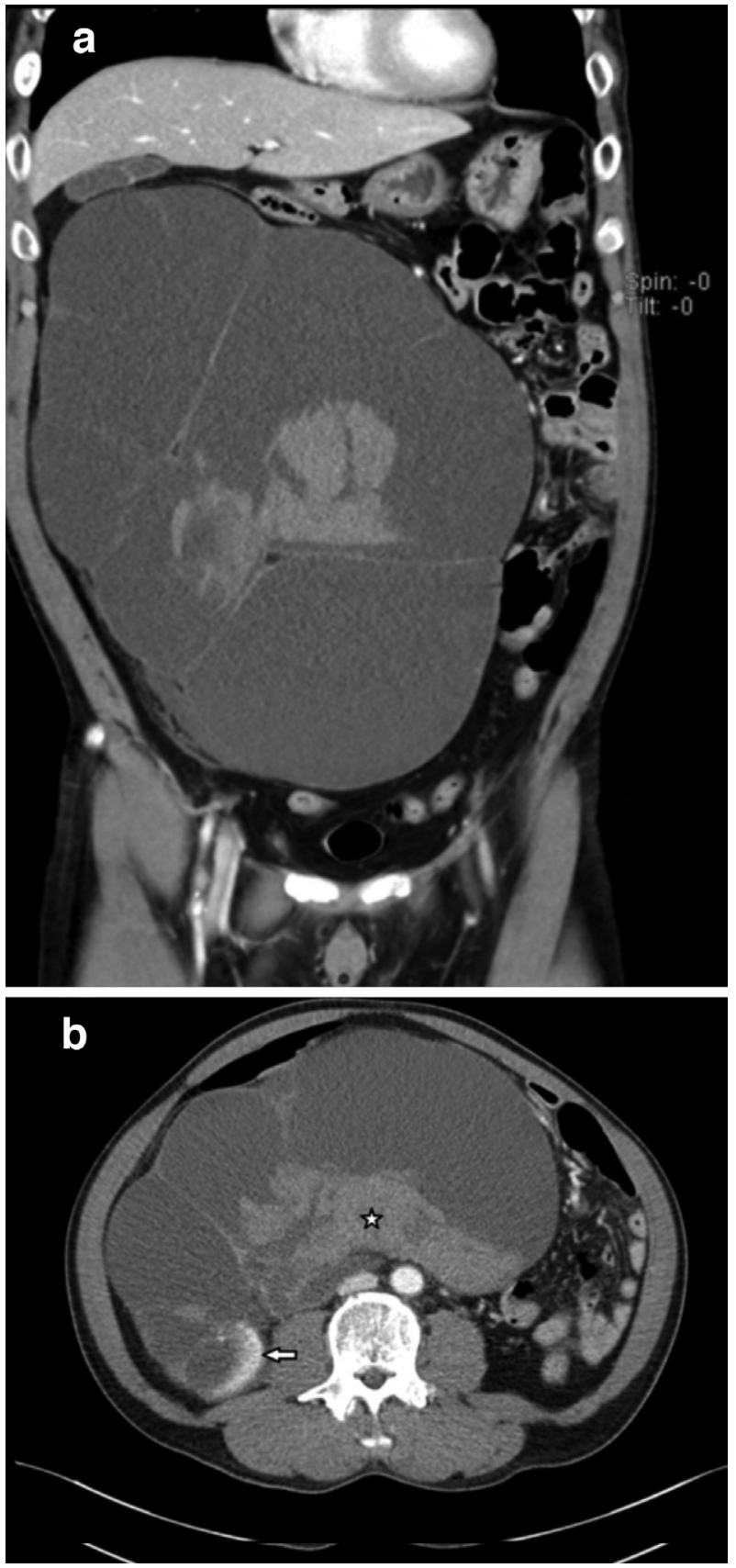

Figure 1. Computed tomography images in coronal (a) and axial (b) sections showing; a) The huge renal mass is seen here displacing the abdominal organs, b) Note an area of avid enhancement posteriorly (arrow), and minimal enhancement of the renal parenchyma with a central solid heterogenous focus (star); which was initially thought to represent a tumor/hematoma

The patient then underwent an open right nephrectomy. A total of $1500 \mathrm{~mL}$ of blood stained fluid was collected intraoperatively. Histopathological examination revealed features of chronic hydronephrosis with an incarcerated calculus in the proximal right ureter. No atypical cells suggestive of malignancy. Patient otherwise recovered well postoperatively. Informed consent was obtained, and patient's anonymity has been maintained.

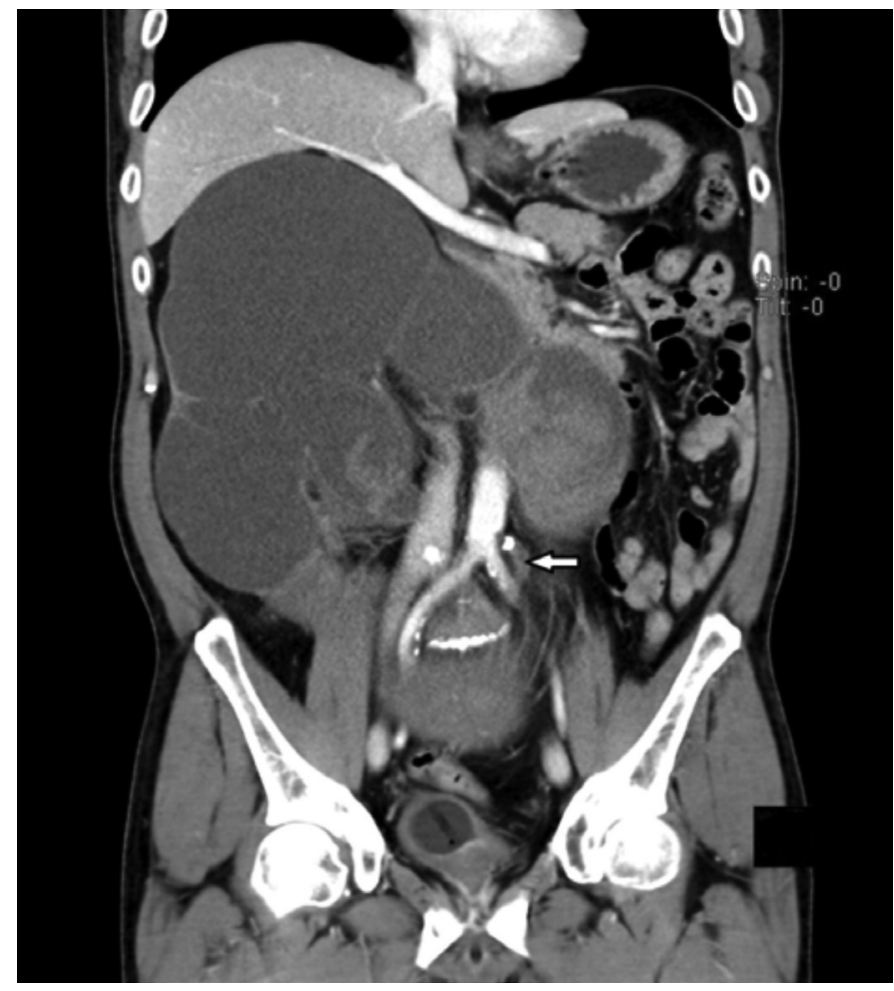

Figure 2. Computed tomography image in coronal section showing the incarcerated calculus in the displaced proximal right ureter (arrow)

\section{Discussion}

Giant hydronephrosis was defined by Stirling (1) in 1939, as the presence of more than $1000 \mathrm{~mL}$ of fluid in the collecting system $(2,3)$. Most cases occur in children; uncommonly in adults and result from obstruction by calculus (4). When present, they may often be misdiagnosed and mistaken for a tumor $(4,5)$. This was demonstrated in our case. Among the differentials for giant cystic masses in the abdomen include intraperitoneal cysts (mesenteric or choledochal), retroperitoneal cysts (renal, adrenal, or pancreatic in origin), ovarian cysts and tumors, and to a certain extent, gross ascites. Once the diagnosis has been established, evaluation of renal function may be undertaken via nuclear studies, prior to deciding whether to proceed with nephrectomy. In the event that renal function is satisfactory, nephrectomy may be avoided. Other conditions where nephrectomy may not be chosen as the definitive treatment include bilateral disease, and disease affecting a younger age group. In our case, as the contralateral kidney was functioning normally, and that there were signs of active hemorrhage in the diseased kidney, total nephrectomy was deemed the most appropriate treatment plan.

\section{Ethics}

Informed Consent: It was obtained.

Peer-review: Externally and internally peer-reviewed. 


\section{Authorship Contributions}

Surgical and Medical Practices: M.S.F.M.N., A.M.A.R., Concept: M.S.F.M.N., Design: A.M.A.R., Data Collection or Processing: M.S.F.M.N., Analysis or Interpretation: M.S.F.M.N., Literature Search: M.S.F.M.N., A.M.A.R., Writing: M.S.F.M.N.

Conflict of Interest: The authors declared no conflict of interest.

Financial Disclosure: The authors declared that this study received no financial support.

\section{References}

1. Stirling WC. Massive hydronephrosis complicated by hydroureter. Report of 3 cases. J Urol 1939; 42:520-533.

2. Wu CC, Sun GH. Giant hydronephrosis. Mayo Clin Proc 2009;84:954.

3. Sepulveda L, Rodrigues F. Giant hydronephrosis - a late diagnosis of ureteropelvic junction obstruction. World J Nephrol Urol 2013;2:33-35.

4. Yang WT, Metreweli C. Giant hydronephrosis in adults : the great mimic. Early diagnosis with ultrasound. Postgrad Med J 1995;71:409-412.

5. Schrader AJ, Anderer G, Knobloch RV, Heidenreich A, Hofmann R. Giant hydronephrosis mimicking progressive malignancy. BMC Urol 2003;3:4. 